\title{
One Year of Lamivudine Therapy for Portuguese Patients with Chronic Hepatitis B
}

\author{
J. Areias, ${ }^{1}$ F. Calinas, ${ }^{2}$ A. Porto, ${ }^{3}$ A. Carvalho, ${ }^{3}$ D. Freitas, ${ }^{3}$ G. Macedo, ${ }^{4}$
} R. Noronha, ${ }^{5}$ J. Cotter, ${ }^{6}$ A. Meliço-Silvestre, ${ }^{3}$ R. Peixe, ${ }^{7}$ J. Pratas, ${ }^{8}$ D. Barrote, ${ }^{9}$ R. Teixeira, ${ }^{10}$ F. Augusto, ${ }^{11}$ I. Carrilho, ${ }^{12}$ F. Campante, ${ }^{13}$ J. Velosa, ${ }^{14}$ L. Carvalho, ${ }^{15}$ M.A. Duarte, ${ }^{16}$ H. Guerreiro, ${ }^{17}$ C. Pires, ${ }^{18}$ A. Silva, ${ }^{19}$ I. Cotrim, ${ }^{20}$ F. Guedes, ${ }^{1}$ L. Tomé, ${ }^{4}$ M. Marcelino, ${ }^{5}$ C. Gonçalves, ${ }^{5}$ E. Ferreira, ${ }^{3}$ L. Matos, ${ }^{7}$ P. Peixe, ${ }^{7}$ J. Esteves, ${ }^{8}$ T. Valente, ${ }^{8}$ C. Simões, ${ }^{8}$ C. Marinho, ${ }^{9}$ L. Jasmins, ${ }^{10}$ M.J. Vieira, ${ }^{13}$ R. Marinho, ${ }^{14}$ P. Matos, ${ }^{15}$ J. Estevens ${ }^{17}$ J. Carrasquinho, ${ }^{18}$ G. Salcedo, ${ }^{21}$ P. Parada ${ }^{22}$ and C. Teixeira ${ }^{22}$

1 Hospital Geral de Santo António, Oporto, Portugal

2 Subgrupo Hospitalar Capuchos-Desterro, Lisbon, Portugal

3 Hospitais da Universidade de Coimbra, Coimbra, Portugal

4 Hospital de S. João, Oporto, Portugal

5 Hospital de S. Marcos, Braga, Portugal

6 Hospital Senhora da Oliveira, Guimarães, Portugal

7 Hospital de Egas Moniz, Lisbon, Portugal

8 Hospital de S. José, Lisbon, Portugal

9 Hospital Padre Américo, Paredes, Portugal

10 Centro Hospitalar do Funchal, Funchal, Portugal

11 Hospital de S. Bernardo, Setúbal, Portugal

12 Hospital Fernando da Fonseca, Amadora, Portugal

13 Hospital N. S. do Rosário, Barreiro, Portugal

14 Hospital de Santa Maria, Lisbon, Portugal

15 Hospital de S. Pedro, Vila Real, Portugal

16 Hospital de Ponta Delgada, Ponta Delgada, Portugal

17 Hospital Distrital de Faro, Faro, Portugal

18 Hospital de Santa Luzia, Viana do Castelo, Portugal

19 Hospital de S. Teotónio, Viseu, Portugal

20 Hospital de St. André, Leiria, Portugal

21 Endoclab, Oporto, Portugal

22 GlaxoSmithKline Portugal, Lisbon, Portugal

\section{Abstract}

Objective: To assess the efficacy of lamivudine treatment on hepatitis B e antigen $(\mathrm{HBeAg})$ and/or hepatitis B surface antigen ( $\mathrm{HBsAg})$ seroconversion, on other virological and serological markers of response including hepatitis B virus (HBV) DNA and serum aminotransferases, and the safety of lamivudine treatment in hepatitis B patients. 
Patients: This phase III open-label study evaluated the virological and biochemical response to lamivudine in 70 Portuguese patients with $\mathrm{HBeAg}$ positive chronic hepatitis B. Patients were treated with lamivudine $100 \mathrm{mg}$ once daily for 12 months.

Methods: Antiviral activity was assessed by measuring alanine aminotransferase (ALT)/aspartate aminotransferase (AST) levels at all protocol visits, and hepatitis B serology and HBV DNA were performed at baseline and at month 12 visits. Evaluation of safety and tolerance was based on clinical adverse events and laboratory analyses.

Results: The primary endpoint was virological response at month 12, defined as loss of detectable $\mathrm{HBeAg}$ from serum with a reduction of HBV DNA to undetectable levels, and this was observed in 19/69 (27.5\%) of patients. Almost half of the patients were HBV DNA negative by this time. Mean ALT values decreased steadily during treatment and by 12 months $61 \%$ of patients had values within the normal range. $\mathrm{HBeAg}$ seroconversion ( $\mathrm{HBeAg}$ negative, $\mathrm{HBeAb}$ positive) was achieved in $27.9 \%$ of patients by 12 months, although all patients remained HBsAg positive.

Conclusion: Lamivudine was well tolerated and the incidence of adverse events was similar to those reported in previous studies. Lamivudine treatment resulted in virological and biochemical improvements in $\mathrm{HBeAg}$ positive chronic hepatitis B patients, with $\mathrm{HBeAg}$ seroconversion in one-third of patients.

Hepatitis B virus (HBV) infection constitutes a major global health problem. Estimates for the year 2000 by the WHO were for 400 million people worldwide to be chronically infected with HBV. ${ }^{[1]}$ Chronic HBV carriers with evidence of active HBV replication are at highest risk for the development of progressive liver disease. ${ }^{[2,3]}$ Approximately half of adult HBV carriers have evidence of viral replication, and in this group 15-20\% may develop cirrhosis within 5 years. ${ }^{[4-7]}$ For patients with HBV-associated chronic hepatitis and cirrhosis, 5-year survival rates as low as $55 \%$ have been reported; for patients with cirrhosis and signs of hepatic insufficiency, 5-year survival may be as low as $14 \% .^{[2,8]} \mathrm{In}$ addition, there is a significantly increased incidence of hepatocellular carcinoma in patients with chronic hepatitis $\mathrm{B}(\mathrm{CHB}){ }^{[9]}$

The goal of antiviral therapy for HBV infection is to reduce the risk of progressive liver disease by providing long-term suppression or eradication of $\mathrm{HBV}$ infection. Lamivudine is the first oral antiviral therapy approved for the treatment of CHB. Lamivudine is a nucleoside analogue that rapidly and profoundly suppresses hepatitis B virus replication through inhibition of viral DNA synthesis. Previous studies have shown that, for patients with CHB, 1 year of lamivudine therapy resulted in persistent suppression of HBV DNA, and a significantly enhanced hepatitis $\mathrm{B}$ e antigen ( $\mathrm{HBeAg}$ ) seroconversion rate with significant reductions in necroinflammatory activity and delayed progression of fibrosis compared with placebo. ${ }^{[10-13]}$ Lamivudine treatment was also associated with a significant reduction in progression to cirrhosis compared with placebo. ${ }^{[9]}$ The aim of the current study was to assess the efficacy ( $\mathrm{HBeAg}$ and hepatitis B surface antigen [HBsAg] seroconversion and other serological markers of response) and safety of lamivudine $100 \mathrm{mg}$ taken once daily for 1 year in 70 Portuguese patients with chronic hepatitis B.

\section{Patients and Methods}

\section{Study Participants}

Patients eligible for enrolment into this openlabel study included males and females 16-70 years 
of age with detectable $\mathrm{HBsAg}$ and $\mathrm{HBeAg}$ in serum at the time of screening and detectable HBsAg for at least the previous 6 months, detectable serum HBV DNA levels (DNA enzyme immunoassay detection system, DiaSorin, Vercelli, Italy) and alanine aminotransferase (ALT) levels of between 1.3 and 10 times the upper limit of the normal reference range (ULN) at screening. Patients were excluded if they had hepatitis C or D or HIV infection; decompensated liver disease (defined by a serum bilirubin level more than 2.5 times ULN, a prothrombin time prolonged by more than 3 seconds, and a serum albumin level lower than the normal reference range or a history of ascites, variceal haemorrhage or hepatic encephalopathy); or evidence of autoimmune hepatitis. Patients were also excluded if they had received an investigational drug within 30 days before enrolment, or were known to require any systemic antiviral therapy, immunomodulators, cytotoxic agents or corticosteroids. Pregnant and lactating females were excluded.

All patients provided written informed consent before participating in the study.

\section{Study Design and Evaluations}

The study protocol was approved by Ethics Committees at each of the institutions involved, and was performed at 22 investigational centres in Portugal according to the latest version of the Declaration of Helsinki. Patients received open-label lamivudine $100 \mathrm{mg}$ once daily for 52 weeks. No interim analyses were performed.

The screening visit was carried out within 4 weeks of the baseline visit, at which study medication was dispensed. After the baseline visit, patients returned every 3 months up to month 12 , for assessment. At the screening visit and at month 12 (or after withdrawal from the study), serum was assayed for HBV DNA (DNA enzyme immunoassay detection system - limit of detection: 1000 copies), HBsAg and anti-HBs if HBsAg was undetectable (Chemiluminiscencs, Diagnostic Product Corporation, Los Angeles, CA, USA), HBeAg and anti$\mathrm{HBe}$ (ELFA Enzyme Linked Fluorescent Assay, Biomerieux Marcy, l'Etoile, France) by a single laboratory (Endoclab, Laboratorio de Endocrinologia e Patologia Clinica, Porto, Portugal). At each visit, a physical examination was carried out and routine haematological and biochemical assays were performed to determine the safety of the treatment. Adverse events that had occurred since the previous visit were also recorded. The study was not designed to evaluate compliance with study medication. Virological testing for YMDD variant was not included in the protocol.

The study design was as similar to routine standard clinical practice as possible, therefore there were no specific requirements for liver biopsies; however, prior biopsy results could be recorded. The disease stage was assessed as follows; (i) inflammation/activity graded as none, mild, moderate or severe; (ii) fibrosis (disease stage) evaluated as none, mild, moderate or severe. Presence or absence of cirrhosis was also indicated. No specific scale system was used, as these were the results of patient biopsies performed prior to study entry. No posttreatment biopsies were required by the protocol.

\section{Data Analysis}

All patients were receiving open-label treatment, and since there were no planned treatment comparisons, only descriptive statistics are presented for the efficacy data. For the analysis of biochemical and virological response, patients with missing data were included and treated as having no response. For the analysis of median values of liver enzymes, only patients with data available were included.

\section{Results}

\section{Patient Accountability}

A total of 70 patients were enrolled into the study and included in the intent-to-treat population. One patient who was $\mathrm{HBeAg}$ negative before entering the study was excluded from the statistical analysis. Four patients had missing month 12 visit data and were treated as having no response in the intent-to treat analysis of virological response. Seven patients withdrew before the end of the study, although three of these still returned for a follow-up assessment. 
Table I. Baseline characteristics of the 70 patients with $\mathrm{HBeAg}$ positive chronic hepatitis $B$ enrolled into the study

\begin{tabular}{ll}
\hline Age $(\mathrm{y})$ & 30.6 (range 16-67.2) \\
Sex (\% male) & $68.6(48 / 70)$ \\
$\%$ of patients HBeAg positive & $98.6(69 / 70)$ \\
$\%$ of patients HBeAb positive & $1.4(1 / 70)$ \\
$\%$ of patients HBsAg positive & $100(69 / 69)$ \\
$\%$ of patients HBV DNA positive & $100(70 / 70)$ \\
ALT (U/L) & 50 (range 30-198)
\end{tabular}

Liver biopsy - severity of inflammation: \% of patients with None $2.0(1 / 51)$

Mild $62.7(32 / 51)$

Moderate $35.3(18 / 51)$

Severe 0

Disease stage (fibrosis): \% of patients with

$\begin{array}{ll}\text { None } & 26.9(14 / 52) \\ \text { Mild } & 55.8(29 / 52) \\ \text { Moderate } & 9.6(5 / 52) \\ \text { Severe } & 7.7(4 / 52) \\ \text { Cirrhosis } & 0\end{array}$

$\overline{\mathrm{ALT}}=$ alanine aminotransferase; $\mathrm{HBeAb}=$ antibody to $\mathrm{HBeAg}$; $\mathbf{H B e A g}=$ hepatitis $\mathrm{B}$ e antigen; $\mathbf{H B s} \mathbf{A g}=$ hepatitis $\mathrm{B}$ surface antigen; $\mathbf{H B V}=$ hepatitis $B$ virus.

Three patients withdrew because of adverse events and four due to 'other' reasons. Results are presented for the intent-to-treat population.

\section{Baseline Characteristics}

The baseline characteristics of the 70 patients in the intent-to-treat population are shown in table I. Sixty-nine percent of patients were male (48/70), with a median age of 30.6 years (range 16-67.2 years). At baseline 69/70 (98.6\%) were HBeAg positive and 69/70 (98.6\%) were HBeAb negative (68/ 70 were both $\mathrm{HBeAg}$ positive and $\mathrm{HBeAb}$ negative). All patients with data recorded (69/69) were HBsAg positive and all patients were HBV DNA positive. Sixty-nine of 70 patients had ALT values available at baseline at which time 68 (99\%) had values between 1.3 and $10 \times \mathrm{ULN}$; the median baseline ALT value was $89 \mathrm{U} / \mathrm{L}$ (range 45-390 U/ L). Seventy percent of patients (48/69) had previously received hepatitis B therapy, i.e. interferon$\alpha$, the standard therapy available at the time of the study, and were non-responders.
Liver biopsies showed that at baseline 32/51 patients $(62.7 \%)$ had a mild severity grading of inflammation, 18/51 (35.3\%) patients had moderate inflammation and no patients had severe inflammation. Twenty-nine patients of $52(55.8 \%)$ had mild fibrosis (enlarged, fibrotic portal tracts), five patients $(9.6 \%)$ had moderate fibrosis (periportal or portal-portal septa, but with intact architecture), four patients had severe fibrosis (architectural distortion), but no patients had cirrhosis.

\section{Virological and Biochemical Response}

In the intent-to-treat population, 19/69 (27.5\%) of the patients who were $\mathrm{HBeAg}$ positive at baseline had a virological response, defined as loss of detectable $\mathrm{HBeAg}$ from serum with a reduction of HBV DNA to undetectable levels (table II). Twenty-two patients $(31.9 \%)$ were $\mathrm{HBeAg}$ negative and 33 (47.1\%) were HBV DNA negative. Figure 1 shows the mean serum ALT and AST values (U/L) throughout the treatment period. ALT values decreased steadily from a median baseline value of 89 U/L (range 45-390 U/L) to $27 \mathrm{U} / \mathrm{L}$ (6-550 U/L) by 12 months. At baseline, no patients had ALT values within the normal range, but this increased to $61.4 \%$ (43/70) of patients by 12 months. Similarly, median aspartate aminotransferase (AST) levels steadily decreased from a baseline value of $50 \mathrm{U} / \mathrm{L}$ (range

Table II. Virological and biochemical responses at 12 months in the intention-to-treat population ${ }^{\mathrm{a}}$

\begin{tabular}{ll}
\hline Percentage of patients & \\
\hline HBeAg negative/HBV DNA negative & $27.5\left(19 / 69^{\mathrm{b}}\right)$ \\
HBeAg negative & $31.9\left(22 / 69^{\mathrm{b}}\right)$ \\
HBV DNA negative & $47.1(33 / 70)$ \\
With HBeAg seroconversion & $27.9\left(19 / 68^{\mathrm{c}}\right)$ \\
HBsAg positive & $100(69 / 69)$ \\
With normal ALT & $61.4(43 / 70)$ \\
With normal AST & $74.3(52 / 70)$
\end{tabular}

a For the virological responses, patients with missing month 12 data $(n=4)$ were treated as non-responders. For biochemical responses, patients with missing month 12 data $(n=10$ for ALT and $n=13$ for AST) were treated as non-responders.

b One patient was $\mathrm{HBeAg}$ negative at baseline.

c One patient was $\mathrm{HBeAb}$ positive at baseline.

ALT = alanine aminotransferase; $\mathbf{A S T}=$ aspartate aminotransferase; $\mathbf{H B e} \mathbf{A g}=$ hepatitis $\mathrm{B}$ e antigen; $\mathbf{H B s} \mathbf{A g}=$ hepatitis $\mathrm{B}$ surface antigen; HBV = hepatitis B virus. 
30-198 U/L) to $24 \mathrm{U} / \mathrm{L}$ (range 10-300 U/L) at month 12 , by which time $74.3 \%$ of patients $(52 / 70)$ had values within the normal range.
Hepatitis B e Antigen and Hepatitis B Surface Antigen Seroconversion

Of the 70 patients in the intent-to-treat population, 68 were both $\mathrm{HBeAg}$ positive and $\mathrm{HBeAb}$ negative at baseline. Of these, $19(27.9 \%)$ achieved
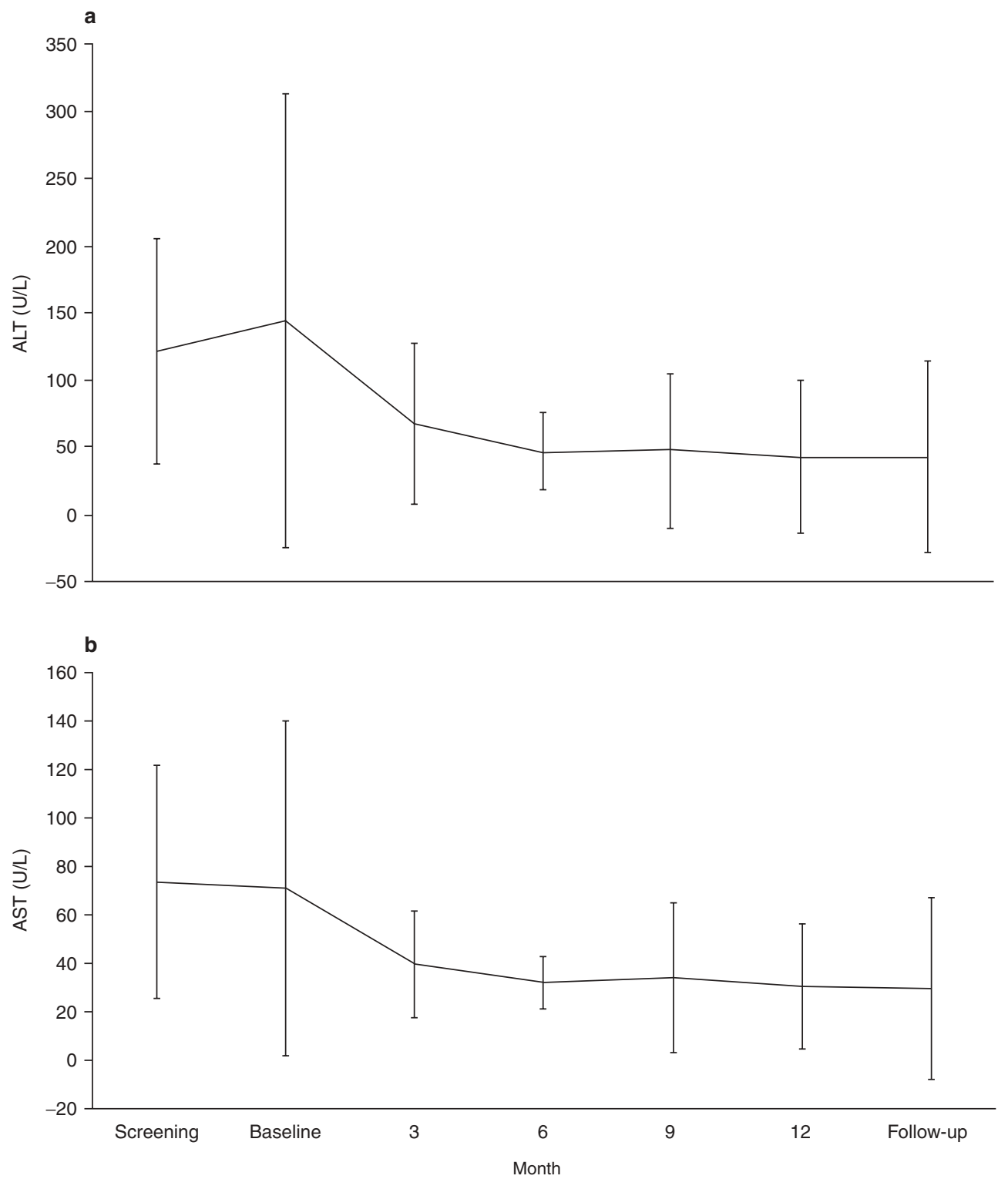

Fig. 1. Mean (a) alanine aminotransferase (ALT) and (b) aspartate aminotransferase (AST) levels (U/L) for hepatitis $B$ patients during 12 months of treatment with lamivudine. Vertical lines represent mean \pm SD. 
$\mathrm{HBeAg}$ seroconversion ( $\mathrm{HBeAg}$ negative, $\mathrm{HBeAb}$ positive) by 12 months. One further patient was $\mathrm{HBeAg}$ negative with borderline $\mathrm{HBeAb}$ by 12 months and another patient was $\mathrm{HBeAg}$ negative/ $\mathrm{HBeAb}$ negative. Of the two patients who were not $\mathrm{HBeAg}$ positive/HBeAb negative at baseline, one was positive for both at baseline and lost $\mathrm{HBeAg}$ by month 12 and the other was negative for both and gained HBeAg by month 12 . No patients lost HBsAg during the study.

\section{Safety}

The mean duration of treatment was $365 \pm 20$ days, and the drug was well tolerated during this treatment period. The overall incidence of adverse events was $40 \%$ (28/70). Only five patients (7.1\%) experienced a serious adverse event, of which three led to study withdrawal. The serious events were pregnancy, intracranial haemorrhage, dermatitis, abdominal pain and elevated creatinine phosphokinase; the latter two events were considered by the investigator to be attributable to lamivudine treatment. In total, ten patients (14.3\%) experienced adverse events considered by the investigator to be drug-related. Table III shows the proportion of patients experiencing the most common adverse events $(\geq 5 \%)$; these were abdominal discomfort and pain, headaches, malaise/fatigue, viral respiratory infections and hair loss/alopecia.

ALT values $>10 \times \mathrm{ULN}$ were noted in five patients $(7 \%)$ at month 2 and then in one patient at month $8(1 \%)$ and one patient at month $12(2 \%)$.

\section{Discussion}

In chronic HBV carriers, only 1-2\% will lose $\mathrm{HBsAg}$ per year, thus many remain infected for their

Table III. Proportion of patients experiencing the most common adverse events $(\geq 5 \%)$

\begin{tabular}{ll}
\hline Adverse event & $\begin{array}{l}\text { No. of patients with } \\
\text { adverse events (\%) }\end{array}$ \\
\hline Abdominal discomfort and pain & $4(5.7)$ \\
Headaches & $4(5.7)$ \\
Malaise and fatigue & $4(5.7)$ \\
Viral respiratory infections & $5(7.1)$ \\
Hair loss and alopecia & $4(5.7)$ \\
\hline
\end{tabular}

lifetime. ${ }^{[14]}$ These individuals have a greatly increased risk of severe liver disease and death from cirrhosis or primary hepatocellular carcinoma; one retrospective analysis of chronic HBV infection indicated that $40 \%$ of adult Asian men with this disease will die of either cirrhosis or hepatocellular carcinoma. ${ }^{[9]}$

Patients with CHB who achieve HBeAg or HBsAg seroconversion typically maintain states of reduced HBV replication (or HBV elimination) for prolonged periods, often for life, and are thought to be at reduced risk for subsequent progression of their liver disease. ${ }^{[15-21]}$ This is thought to be true for both spontaneous and treatment-induced $\mathrm{HBeAg}$ seroconversions. Treatment with interferon- $\alpha$ can produce $\mathrm{HBeAg}$ seroconversion in approximately $20-40 \%$ of treated patients. ${ }^{[21-23]}$ However, patients who have high levels of serum HBV DNA or minimal evidence of inflammatory response (e.g. low serum ALT levels) appear to have lower response rates to interferon therapy. ${ }^{[23]}$ Furthermore, interferon use in patients with advanced liver disease requires particular caution. ${ }^{[24-26]}$ Hence, although interferon has been an important first step in hepatitis B therapy, widespread clinical acceptance of interferon treatment has been limited by its inconvenience (parenteral dosing), side effect profile, costs and lack of response in the majority of patients.

Lamivudine is the first oral antiviral therapy approved for the treatment of CHB. It is a nucleoside analogue that rapidly and profoundly suppresses HBV replication through inhibition of viral DNA synthesis. The efficacy and safety of lamivudine in CHB has been extensively studied in the Far East, the US and Europe and shows that lamivudine provides a rapid and consistent suppression of serum HBV levels with normalisation of ALT. ${ }^{[10,11,27,28]}$ Through its viral inhibition, lamivudine treatment results in enhanced seroconversion and reduced hepatic necroinflammatory activity and therefore appears to slow the progression of fibrosis in patients with ongoing viral replication and compensated liver disease. ${ }^{[10-13]}$

Newer pharmacotherapeutic agents are being developed and hold promise for the treatment of HBV 
precore/core mutant. ${ }^{[29]}$ Adefovir dipivoxil is a recently approved nucleotide analogue for the treatment of chronic hepatitis B infection. ${ }^{[30,31]}$

\section{Conclusion}

In this study of 70 Portuguese patients, HBV DNA responses to lamivudine therapy were similar to those reported elsewhere, with 47\% (33/70) of patients having suppression of HBV DNA to undetectable levels after 52 weeks of lamivudine therapy. Improvements in ALT were also observed, with median values approaching the normal range after 6 months. Sixty-one percent of patients had ALT values within the normal range after 52 weeks of therapy, reflecting rates reported in other studies. ${ }^{[10]}$ Such normalisation of serum ALT is indicative of reduced liver damage, since serum ALT concentrations are thought to correlate reasonably well with liver disease measured histologically. ${ }^{[32]}$

$\mathrm{HBeAg}$ seroconversion is a desirable goal in the treatment of CHB since it is recognised as being associated with a durable suppression of HBV replication with an improved clinical prognosis. ${ }^{[33]}$ In this study, after 52 weeks of lamivudine therapy $\mathrm{HBeAg}$ seroconversion (loss of detectable $\mathrm{HBeAg}$ and the appearance of anti-HBe) occurred in $27.9 \%$ $(19 / 68)$ of patients. This is in agreement with other placebo-controlled lamivudine studies conducted elsewhere, reporting that $17-21 \%$ had seroconversion after 1 year. ${ }^{[10,11,27]}$ Most patients who had loss of HBeAg also had lost detectable HBV DNA, suggesting that $\mathrm{HBeAg}$ loss is associated with a marked suppression of HBV replication. The rate of $\mathrm{HBeAg}$ loss was higher than the rate of $\mathrm{HBeAg}$ seroconversion, although the difference was not as great as that reported in some studies. ${ }^{[11,27]}$ The rate of $\mathrm{HBeAg}$ loss was similar to that reported in a meta-analysis of interferon therapy $(33 \%) .{ }^{[21]}$

Lamivudine has an excellent, well-established safety and tolerability profile in patients with $\mathrm{HBeAg}$ positive $\mathrm{CHB}$, with evidence to show that this tolerability is maintained with extended treatment for up to 4 years. ${ }^{[10,28,34,35]}$ In previous clinical trials the incidence of adverse events in lamivudineor placebo-treated patients was similar during 1 year of therapy, where most were mild and not considered to be related to lamivudine. ${ }^{[10-12,27,28]}$ Analyses of the subset of adverse events considered to be possibly or probably related to the study drug or of unknown relationship revealed similar frequencies of such events for patients treated with lamivudine or placebo. The incidence of adverse events in this Portuguese study was in keeping with these findings and revealed a similar profile of most commonly reported adverse events.

In conclusion, this Portuguese study corroborated the findings of earlier studies, showing that lamivudine treatment in patients with $\mathrm{HBeAg}$ positive CHB is well tolerated and results in both virological and biochemical improvements, with $\mathrm{HBeAg}$ seroconversion achieved in one third of patients.

\section{Acknowledgements}

Funding for the study (protocol no. NUCPT01) was provided by Glaxo Wellcome Portugal.

We gratefully acknowledge technical assistance from Dr Graça Salcedo at the Laboratório de Endocrinologia e Patologia Clínica, Porto, Portugal and the other members of the Portuguese Lamivudine Study group: J. Areias, F. Calinas, A. Porto, A. Carvalho, D. Freitas, G. Macedo, R. Noronha, J. Cotter, A. Meliço-Silvestre, R. Peixe, J. Pratas, D. Barrote, R. Teixeira, F. Augusto, I. Carrilho, F. Campante, J. Velosa, L. Carvalho, M.A. Duarte, H. Guerreiro, C. Pires, A. Silva, I. Cotrim, F. Guedes, L. Tomé, M. Marcelino, C. Gonçalves, E. Ferreira, L. Matos, P. Peixe, J. Esteves, T. Valente, C. Simões, C. Marinho, L. Jasmins, M.J. Vieira, R. Marinho, P. Matos, J. Estevens, J. Carrasquinho, P. Parada, C. Teixeira.

\section{References}

1. Lee WM. Hepatitis B virus infection. N Engl J Med 1997; 337 : $1733-45$

2. De Jongh FE, Jamssea HL, De Man RA, et al. Survival and prognostic indicators in hepatitis B surface antigen-positive cirrhosis of the liver. Gastroenterology 1992; 103: 1630-5

3. Hadziyannis SJ, Lieberman HM, Karvountzis GG, et al. Analysis of liver disease, nuclear $\mathrm{HBcAg}$, viral replication, and hepatitis B virus DNA in liver and serum of $\mathrm{HBeAg}$ vs antiHBe positive carriers of hepatitis B virus. Hepatology 1983; 3: 656-62

4. Alberti A, Pontisso P, Fattovich G, et al. Changes in serum hepatitis B virus (HBV) DNA positively in chronic HBV infection: Results of a long-term follow-up study of 138 patients. J Infect Dis 1986; 154: 562-9

5. Chu CM, Liaw YF. Intrahepatic distribution of hepatitis B surface and core antigens in chronic hepatitis B virus infection. Gastroenterology 1987; 92: 220-5 
6. Liaw YF, Tai DI, Chu CM, et al. The development of cirrhosis in patients with chronic type B hepatitis: a prospective study. Hepatology 1988; 8: 493-6

7. Fattovich G, Brollo L, Giustina G, et al. Natural history and prognostic factors for chronic hepatitis type B. Gut 1991; 32: 294-8

8. Weissberg JI, Andres LL, Smith CI, et al. Survival in chronic hepatitis B: an analysis of 379 patients. Ann Intern Med 1984; 101: 613-6

9. Beasley RP. Hepatitis B virus: the major etiology of hepatocellular carcinoma. Cancer 1988; 61: 1942-56

10. Lai CL, Chien RN, Leung NWY, et al. A one year trial of lamivudine for chronic hepatitis B. N Engl J Med 1998; 339: 61-8

11. Dienstag J, Schiff ER, Wright TL, et al. Lamivudine as initial treatment for chronic hepatitis B in the United States. N Engl J Med 1999; 341: 1256-63

12. Schalm SW, Heathcote J, Cianciara J, et al. Lamivudine and alpha interferon combination treatment of patients with chronic hepatitis B infection: a randomised trial. Gut 2000; 46: $562-8$

13. Goodman Z, Dhillon AP, Wu PC, et al. Lamivudine treatment reduces progression to cirrhosis in patients with chronic hepatitis B [abstract]. J Hepatol 1999; 30 Suppl. 1: 59

14. Hoofnagle JH, Alter HJ. Chronic viral hepatitis. In: Vyas GN, Dienstag JL, Hoofnagle GH, editors. Viral hepatitis and liver disease. New York: Grune \& Stratton, 1984: 91-113

15. Liaw YF, Chu CM, Su IJ, et al. Clinical and histological events preceding hepatitis $\mathrm{B}$ e antigen seroconversion in chronic type B hepatitis. Gastroenterology 1983; 84: 216-9

16. Fattovich G, Rugge M, Brollo L, et al. Clinical, virologic and histologic outcome following seroconversion from $\mathrm{HBeAg}$ to anti-HBe in chronic hepatitis type B. Hepatology 1986; 6: $167-72$

17. Hoofnagle JH, Dusheiko GM, Seeff LB, et al. Seroconversion from hepatitis B e antigen to antibody in chronic type B hepatitis. Ann Intern Med 1981; 94: 744-8

18. Davis GL, Hoofnagle JH, Waggoner JG. Spontaneous reactivation of chronic hepatitis B virus infection. Gastroenterology 1984; 86: 230-5

19. Perrillo RP, Brunt EM. Hepatic histologic and immunohistochemical changes in chronic hepatitis B after prolonged clearance of hepatitis B e antigen and hepatitis B surface antigen. Ann Intern Med 1991; 115: 113-5

20. Korenman J, Baker B, Waggoner J, et al. Long-Term remission of chronic hepatitis B after alpha-interferon therapy. Ann Intern Med 1991; 114: 629-34

21. Wong DKH, Cheung AM, O'Rourke K, et al. Effect of alphainterferon treatment in patients with hepatitis $\mathrm{B}$ e antigenpositive chronic hepatitis B. Ann Intern Med 1993; 119: 312-23

22. Wong JB, Koff RS, Tinè Fabio, et al. Cost-effectiveness of interferon- $\alpha 2 b$ treatment for hepatitis $B$ e antigen-positive chronic hepatitis B. Ann Intern Med 1995; 122: 664-75
23. Perrillo RP, Schiff ER, Davis GL, et al. A randomised, controlled trial of interferon alfa- $2 \mathrm{~b}$ alone and after prednisone withdrawal for the treatment of chronic hepatitis B. N Engl J Med 1990; 323: 295-301

24. Kassianides C, Di Bisceglie A, Hoofnagle J, et al. Alpha interferon therapy in patients with decompensated chronic type B hepatitis In: Zuckerman AJ, editor. Viral hepatitis and liver diseases. New York: Alan R. Liss, 1988: 840-843

25. Hoofnagle HH, Di Bisceglie AM, Waggoner JG, et al. Interferon alfa for patients with clinically apparent cirrhosis due to chronic hepatitis B. Gastroenterology 1993; 104: 1116-21

26. Nevens F, Goubau P, Van Eyken P, et al. Treatment of decompensated viral hepatitis B-induced cirrhosis with low doses of interferon alpha. Liver 1993; 13: 15-9

27. Schiff E, Karayalcin S, Grimm I, et al. A placebo controlled study of lamivudine and interferon alpha- $2 \mathrm{~b}$ in patients with chronic hepatitis B who previously failed interferon therapy [abstract]. Hepatology 1998; 28: 388A

28. Liaw YF, Leung NWY, Chang TT, et al. Effects of extended lamivudine therapy in Asian patients with chronic hepatitis B. Gastroenterology 2000; 119: 172-80

29. Rivkina A, Rybalov S. Chronic hepatitis B: current and future treatment options. Pharmacotherapy 2002; 22 (6): 721-37

30. Hadziyannis SJ,Tassopoulos NC, Heathcote EJ, et al. Adefovir dipivoxil for the treatment of hepatitis $\mathrm{B}$ e antigen negative chronic hepatitis B. N Eng J Med. 2003 Feb 27; 348 (9): 800-7

31. Marcellin P, Chang TT, Lim SG, et al. Adefovir dipivoxil for the treatment of hepatitis B e antigen positive chronic hepatitis B. N Eng J Med. 2003 Feb 27; 348 (9): 808-16

32. Di Bisceglie, Goodman ZD, Ishak KG, et al. Long-term clinical and histopathological follow-up of chronic post-transfusion hepatitis. Hepatology 1991; 14: 969-74

33. Niederau $C$, Heintges $T$, Lange $S$, et al. Long-term follow-up of HBeAg-positive patients treated with interferon alfa for chronic hepatitis B. N Engl J Med 1996; 3334: 1422-7

34. Leung NWY, Lai CL, Chang TT, et al. Extended lamivudine treatment in patients with chronic hepatitis B enhances hepatitis B e antigen seroconversion rates: results after three years of therapy. Hepatology 2001; 33: 1527-32

35. Chang TT, Lai CL, Liaw YF, et al. Incremental increases in $\mathrm{HBeAg}$ seroconversion and continued ALT normalization in Asian chronic HBV (CHB) patients treated with lamivudine for four years [abstract]. Antivir Ther 2000; 5 Suppl 1): 44

Correspondence and offprints: Dr P. Parada, GlaxoSmithKline Portugal, R. António Loureiro Borges, no. 3, Arquiparque - Miraflores, 1494-131 Algés, Portugal. E-mail: pp24745@gsk.com 
Copyright $\odot 2003$ EBSCO Publishing 